aUniversidade Federal do Oeste da Bahia, Campus Reitor Edgard Santos, CEP 47810-047, Barreiras-BA, Brasil. 'Instituto Federal de Educação Ciência e Tecnologia Baiano, Campus Guanambi, CEP 46430-000, Guanambi-BA, Brasil.

*E-mail: mauro.bueno@ufob.edu.br

Recebido em: 3 de Novembro de 2020

Aceito em: 8 de Abril de 2021

Publicado online: 27 de Setembro de 2021

\section{Antioxidant, Antibacterial Activities and Phytochemical Composition of the Aerial Parts, Stem and Roots of Gomphrena vaga Mart. from Northeast Brazil}

\author{
Atividade Antioxidante, Atividade Antibacteriana e Composição \\ Fitoquímica das Partes Aéreas, Caule e Raízes de Gomphrena vaga Mart. \\ do Nordeste do Brasil
}

\author{
Symone Costa de Castro, ${ }^{a, b}$ Naiara Maia Oliveira, ${ }^{b}$ Janiel Ramos de Oliveira, ${ }^{2}$ Luciana Lucas \\ Machado, ${ }^{a}$ Katyúscya Veloso Leão, ${ }^{a}$ Mauro Alves Bueno ${ }^{a, *(1)}$
}

\begin{abstract}
Brazil is the country with the largest plant diversity in the world, and many of these species are used in traditional medicine. However, a large number of these medicinal plants have not yet been studied. Thus, the present study investigated the species Gomphrena vaga Mart., which is an endemic species in Brazil, belonging to the Amaranthaceae family. This plant is used in traditional medicine as an analgesic and anti-inflammatory. The plant parts studied were its leaves, stem, and root. The phytochemical study was performed using chromatographic methods, while antioxidant and antibacterial activities assays were performed employing in vitro tests using, respectively, the methods of DPPH • and Agar-diffusion technique for E. coli, E. faecalis, S. aureus and S. epidermidis. From the phytochemical study, different fatty acids, saturated and unsaturated, were identified. Also, the sterol 20-hydroxyecdysone was isolated from the root extracts in a significant amount, representing $0.95 \%$ by weight of dry matter. The results of biological assays demonstrated the phytotherapeutic potential of this plant, with a high content of phenolic compounds, mainly in the polar fractions $\left(385.15 \mathrm{mg} \mathrm{EAG.}^{-1}\right.$ of the sample, for the ethyl acetate fraction of the leaves), low values of $\mathrm{EC}_{50}$, between 49.22 and $74.91 \mu \mathrm{g} \cdot \mathrm{ml}^{-1}$, including for 20-hydroxyecdysone $\left(50.55 \mu \mathrm{g} \cdot \mathrm{ml}^{-1}\right)$ and positive results against $S$. epidermidis and $E$. faecalis, with inhibition halos between 9.09 and $12.80 \mathrm{~mm}$. The results obtained in this study contribute to add value to this species, justifying its therapeutic uses.
\end{abstract}

Keywords: Amaranthaceae; 20-hydroxyecdysone; fatty acids.

\section{Introduction}

The first therapeutic resources used by humans to treat diseases came from nature, with plants being the most widely used. ${ }^{1}$ This is due, in large part, to the diversity found in the Plantae kingdom, in addition to the myriad of special or secondary metabolites produced by members of the kingdom.

Notwithstanding the great biodiversity found in the plant kingdom, only six percent of plant species have been investigated pharmacologically and only 15 percent biochemically.,3 A picture of these data is the herbal medicine market in Brazil, the country with the greatest biodiversity in the world, which represents only about 261 million dollars, less than five percent of the world market. ${ }^{4}$ Therefore, efforts should be added to study new species of plants used in popular medicine in Brazil, to incorporate economic value and/or produce new products based on these vegetables.

The genus Gomphrena is among a huge variety of plant genera and families in Brazil, belonging to the Amaranthaceae family. Several species of this genus are used in traditional medicine to treat several diseases.

Biological activities of these species, investigated by many authors, include antimicrobial ${ }^{5,6}$, antitumoral $^{7}$, antioxidant ${ }^{8,9}$, and anesthetics ${ }^{10}$. Regarding the chemical constituents, many metabolites have been described for the family Amaranthaceae and for the genus Gomphrena, those which include steroids, flavonoids, ecdysteroids, betacyanins, and phenolic acids. ${ }^{11}$

The species Gomphrena vaga Mart. was chosen in this study, since it is an endemic plant in Brazil that belongs to the Amaranthaceae family. This species occurs mainly in open and disturbed Brazilian environments such as Caatinga, Cerrado, and rupestrian fields. ${ }^{12}$ 
Popularly known as "pustemeira", "cabeludinha", or even "Thoronoé" (by the Karajás Indians), the species $G$. vaga has a wide distribution throughout South America and, in Bahia State, is found mainly in areas of the Caatinga. G. vaga still has the synonyms of Hebhante vaga (Mart.), Gomphrena holosericea (Mart.) Moq. and Hebhante holosericea Mart. ${ }^{13}$ They are sub-shrubs, semi-climbing, branchy, pubescent; adpressed trees with white trichomes, abundant in young branches. Inflorescences are yellowish or whitish. ${ }^{12}$

The G. vaga Mart., species is used in traditional medicine as an analgesic for toothache, against asthma and allergies and as an anti-inflammatory of the ovaries..$^{12,14,15}$ However, to the best of our knowledge, there are no published reports of previous studies that describe investigations of biological activities or chemical constituents that justify the medicinal properties of this plant.

Thus, we evaluated the antioxidant and antimicrobial activities of the crude extracts and fractions of different polarities of the aerial parts and roots of $G$. vaga. We also investigated the composition of fatty acids, described the isolation of 20-hydroxyecdysone from the root of this species and determined its antioxidant activity, as a way of contributing with useful scientific information to add value to the referred species, justifying its medicinal use.

\section{Materials and Methods}

\subsection{Reagents and equipment}

Chloroform, ethyl acetate, methanol, hexane, DPPH (2,2-diphenyl-1-picryl-hydrazil), were obtained from Sigma Chemical Company, United Kingdom. Silica gel (70-230 Mesh), dimethyl sulfoxide (DMSO), potassium bromide (IR grade), and deuterated methanol were collected from E. Merck, Germany. In the analyzes by Thin-Layer Chromatography (CCD), 20x20 commercial silica gel plates $\left(\right.$ MACHEREY-NAGEL $^{\circledR}$ ) were used. NMR spectra were recorded on a Bruker instrument $(300 \mathrm{MHz})$ on $\mathrm{CD}_{3} \mathrm{OD}$ using TMS as an internal standard. UV spectra were recorded on a Varian spectrophotometer, using methanol ( $\lambda$ max in $\mathrm{nm}$ ). IR spectra were recorded (KBr disks) on a Shimadzu FT-IR spectrometer, validation $\left(v \max\right.$ in $\left.\mathrm{cm}^{-1}\right)$. Mass spectra were recorded in a microOTOF-QII Bruker LC-ESI-MS/MS ESI equipment.

\subsection{Collection and identification}

The leaves, stems, and roots of the species Gomphrena vaga Mart. were collected in the rural area of the municipality of Malhada-BA in February 2018. The location has the following geographical coordinates: S14 37'14.4'; W04339'32.5'". The plant was identified by comparison with exsiccates present in the Herbarium of the Federal University of Western Bahia and registered in the 'Sistema Nacional de Gestão do Patrimônio Genético e do Conhecimento Tradicional Associado' (SISGEN) under number A4B672C.

\subsection{Extraction}

The samples were dried in a circulating air oven at an average temperature of $40^{\circ} \mathrm{C}$ for 72 hours. After drying, the material was grounded separately in a knife mill, resulting in $436.29 \mathrm{~g}$ of leaves, $1,111.62 \mathrm{~g}$ of stem, and $824.87 \mathrm{~g}$ of roots. These samples were subjected to maceration in methanol, for five consecutive extractions, for about 72 hours each; the filtrates obtained in each step were combined and concentrated under reduced pressure at a temperature of approximately $50{ }^{\circ} \mathrm{C}$, resulting in the crude extracts of the stem $(25.93 \mathrm{~g})$, leaf $(28.68 \mathrm{~g})$ and root $(78.16 \mathrm{~g})$. In the liquid-liquid partition process, an amount of the crude methanolic extract was initially suspended in $250 \mathrm{~mL}$ of a methanol:water (7:3), the mixture was transferred to a separating funnel and extracted successively with solvents of different polarities, hexane, chloroform and ethyl acetate. The fractions obtained were concentrated in a rotary evaporator, resulting in fractions of hexane, chloroform and ethyl acetate of the leaves, stem and root of G. vaga Mart.

\subsection{Isolation of 20-hydroxyecdysone from the root}

The ethyl acetate fraction of the root (400 mg) was subjected to column chromatography using silica gel (70-230 Mesh) as stationary phase, and as mobile phase chloroform and methanol, with an increasing gradient of polarity, starting with a mixture of $\mathrm{CHCl}_{3}: \mathrm{MeOH}(9: 1)$. The sample/silica ratio was 1:50, and 125 fractions of approximately $10 \mathrm{~mL}$ each were collected, which, after TLC analysis, visualized respectively, with UV radiation, iodine vapors, and vanillin solution under heating resulted in the grouping of 6 fractions. From one of the combined fractions, $40 \mathrm{mg}$ of a pure substance was obtained as colorless crystals, $\mathrm{Rf}=0.64\left(\mathrm{MeOH}: \mathrm{CHCl}_{3}, 8: 2\right) . \mathrm{IR}(\mathrm{KBr}), \mathrm{cm}^{-1}: 3408(\mathrm{OH})$, $1647(\mathrm{C}=\mathrm{O}), 1055(\mathrm{C}-\mathrm{O}) ; \mathrm{UV}(\mathrm{MeOH}) \lambda_{\text {máx }} 240 ; \mathrm{ESI}^{+}-\mathrm{MS}^{2}$ $m / z: \mathrm{C}_{27} \mathrm{H}_{44} \mathrm{O}_{7}, 481,3154(\mathrm{M}+\mathrm{H})$ e ESI--MS ${ }^{2} \mathrm{~m} / z: 479,3211$ $(\mathrm{M}-\mathrm{H}) ;{ }^{1} \mathrm{H}$ NMR $\left(300 \mathrm{MHz}, \mathrm{CD}_{3} \mathrm{OD}\right): \delta 0.90(\mathrm{~s}, 3 \mathrm{H}), 0.97$ $(\mathrm{s}, 3 \mathrm{H}), 1.20(\mathrm{~s}, 6 \mathrm{H}), 1.19(\mathrm{~s}, 3 \mathrm{H}), 1.28-2.41(\mathrm{~m}, 16 \mathrm{H}), 5.82$ $(\mathrm{s}, 1 \mathrm{H}), 3.86(\mathrm{~m}, 1 \mathrm{H}), 3.95(\mathrm{~m}, 1 \mathrm{H}), 3.35(\mathrm{~d}, 9 \mathrm{H}), 3,16(\mathrm{t}$, 1H). ${ }^{13} \mathrm{C}$ NMR (75 MHz, $\left.\mathrm{CD}_{3} \mathrm{OD}\right): \delta 18.34,21.32,21.76$, $24.68,27.59,29.24,29.97,32.03,32.76,33.08,35.35$, $37.58,39.55,42.64,48.45,50.15,52.04,68.78,68.96$, 71.62, 78.25, 78.70, 85.53, 122.41, 168.34, 206.88.

\subsection{Determination of total phenolic content}

Initially, a $1.00 \mathrm{mg} \mathrm{mL}^{-1}$ solution in methanol of each extract and fraction in a $10 \mathrm{~mL}$ volumetric flask was prepared. Then, $0.5 \mathrm{~mL}$ of this solution was transferred to a $10 \mathrm{~mL}$ volumetric flask and $6 \mathrm{~mL}$ of distilled water, and $0.5 \mathrm{~mL}$ of the Folin-Ciocalteu reagent was added. The 
resulting mixture was homogenized and after 3 minutes, $1.0 \mathrm{~mL}$ of $15 \%(\mathrm{w} / \mathrm{v}) \mathrm{Na}_{2} \mathrm{CO}_{3}$ solution was added with stirring, and the final volume was completed to $10 \mathrm{~mL}$ with distilled water. A blank, containing methanol and all other reagents was prepared. After $60 \mathrm{~min}$, the resulting mixture was read at $750 \mathrm{~nm}$. The result was expressed in $\mathrm{mg}$ of gallic acid equivalent per gram of extract (EAG.g ${ }^{-1}$ extract), based on the analytical curve of gallic acid ( 10 to $\left.350 \mu \mathrm{g} \mathrm{mL}^{-1}\right)$. The analytical curve, using gallic acid standards, was prepared as described for the extracts.

\subsection{Antioxidant potential - DPPH test}

The free radical scavenging method employing DPPH• (2,2-diphenyl-1-picrylhydrazyl) was used for the in vitro determination of the antioxidant potential of extracts, fractions, and the isolated compound, according to the methodology described in the literature, with modifications. ${ }^{16}$ Sample dilutions were prepared at concentrations of 200, $150,100,50,10$, and $1.0 \mu \mathrm{g} \mathrm{mL}^{-1}$, using a $500 \mu \mathrm{g} \mathrm{mL}^{-1}$ stock solution. The DPPH analytical curve was built from the absorbance values of the solutions made in triplicate, from 1.0 to $40.0 \mu \mathrm{g} \mathrm{mL}^{-1}$, read at $515 \mathrm{~nm}$, in quartz cuvettes with an optical length of $1 \mathrm{~cm}$, using methanol as blank. The reaction mixture was prepared from the combination of the sample solution and the DPPH solution $\left(40 \mu \mathrm{g} \mathrm{mL}^{-1}\right)$, in a 1:1 ratio. After 30 minutes, the absorbance values were measured and the percentage values of remaining DPPH (\% $\left.\mathrm{DPPH}_{\mathrm{REM}}\right)$ were determined by calculating the concentration of DPPH in the medium, using the linear equation $\left(y=50.672 x+0.8412 ; R^{2}=0.9999\right)$. The results were expressed in terms of $\mathrm{EC}_{50}$, which were obtained from the linear regression of the $\% \mathrm{DPPH}_{\mathrm{REM}}$ slopes for the different concentrations of the samples, made in triplicate for each of the samples.

\subsection{Antibacterial activity}

Antibacterial activity of leaves, stem, and root of G. vaga extracts and fractions was evaluated against Gram-negative Escherichia coli ATCC $^{\circledR} 25922$ and the three Gram-positive bacteria, Enterococcus faecalis ATCC $^{\circledR}$ 29212, Staphylococcus aureus ATCC $^{\circledR} 25923$, and Staphylococcus epidermidis NEWP ${ }^{\circledR}$ 0128, in MuellerHinton agar Petri dishes using agar diffusion method, with modifications. ${ }^{17}$ Different concentrations of the extracts (400 and $200 \mathrm{mg} \mathrm{mL}^{-1}$ ) and fractions (100 and $50 \mathrm{mg} \mathrm{mL}$ $\left.{ }^{1}\right)$, were prepared in water, using Tween $20(0.5 \% \mathrm{v} / \mathrm{v})$ to aid dilution. Lactic acid $40 \% \mathrm{v} / \mathrm{v}$ solution was used as a positive control. Wells, of approximately $5 \mathrm{~mm}$ in diameter, were made in the inoculated agar dishes. Subsequently, 20 $\mu \mathrm{L}$ of the extracts, fractions, and control solutions were added to each well. The diameter of the inhibition zones for the tested bacteria was measured with a digital caliper after $48 \mathrm{~h}$ of incubation period. Each experiment was performed in triplicate.

\subsection{Fatty acids esterification}

Hexane fraction saponification was carried out by mixing $\mathrm{NaOH} 4.0 \mathrm{~g}(10 \mathrm{mmol})$ and $1.5 \mathrm{~g}$ of the sample in a $125 \mathrm{~mL}$ round-bottom flask containing $50 \mathrm{~mL}$ of methanol, and the mixture was heated under reflux for 6 hours. After the reaction was complete, the mixture was transferred to a separatory funnel and extracted with three portions of $50 \mathrm{~mL}$ of ethyl ether. The aqueous phase was acidified with five drops of concentrated $\mathrm{HCl}$ and heated for 10 minutes. The mixture was transferred to a separatory funnel containing $30 \mathrm{~mL}$ of water and extracted with 3 portions of $50 \mathrm{~mL}$ of ethyl ether. The combined organic phases were dried over anhydrous sodium sulfate, filtered, and concentrated under reduced pressure. The crude product was purified by chromatography, using silica gel as a stationary phase and a gradient of hexane/ ethyl acetate/methanol, starting with 90:5 v/v of hexane/ethyl acetate and finishing with $90: 10 \mathrm{v} / \mathrm{v}$ of methanol/ethyl acetate.

\subsection{Gas-chromatography}

CG-MS analyzes were performed in a Shimadzu Chromatograph QP2020 equipped with DB-5 column, 5\% phenyl and $95 \%$ methylsiloxane $(30 \mathrm{~m} \times 0.25 \mathrm{~mm} \times 025 \mu \mathrm{m}$, film) using helium as carrier gas $\left(1 \mathrm{~mL} \mathrm{~min}{ }^{-1}\right)$. The conditions for analysis of leaf and stem fractions were as follows: Injector temperature of $180^{\circ} \mathrm{C}$; initial temperature of $80^{\circ} \mathrm{C}$ maintained for 1 minute, increase of $6^{\circ} \mathrm{C} \mathrm{min}^{-1}$ up to $100{ }^{\circ} \mathrm{C}$, then increase of $3{ }^{\circ} \mathrm{C} \mathrm{min}^{-1}$ up to $200{ }^{\circ} \mathrm{C}$ and finally, increase of $15^{\circ} \mathrm{C} \mathrm{min}^{-1}$ up to $300^{\circ} \mathrm{C}(\operatorname{method} \mathrm{A})$ and for the root: injector temperature of $180^{\circ} \mathrm{C}$; initial temperature of $80{ }^{\circ} \mathrm{C}$ maintained for 1 minute, increase of $6{ }^{\circ} \mathrm{C} \mathrm{min}-1$ up to $100{ }^{\circ} \mathrm{C}$, then increase of $3{ }^{\circ} \mathrm{C} \mathrm{min}^{-1}$ up to $200^{\circ} \mathrm{C}$ and finally, increase of $15{ }^{\circ} \mathrm{C} \min ^{-1}$ up to $300{ }^{\circ} \mathrm{C}(\operatorname{method} \mathrm{B})$.

\subsection{Identification of methyl esters}

Methyl esters identification was performed by comparison of the mass spectra obtained with the mass spectra libraries available, such as NIST (National Institute Standards and Technology) and FFNSC (Flavor and Fragrance Natural and Synthetic Compounds), in which it was considered only those compounds that showed similarity between the fragmentation pattern obtained with those available in the databases greater than or equal to $90 \%$.

\subsection{Statistical analysis}

All experiments were carried out in triplicate, and the average values were calculated. The $F$ test $(p<0.05)$ was calculated for the statistical significance of the results.

\section{Results and Discussion}

After fractionation of the ethyl acetate fraction of the 
root in a chromatographic column, a colorless crystalline solid was obtained, representing $10 \%$ by weight of the crude extract, which represents $0.95 \%$ by weight of the dry matter, whose spectral data were compatible to 20-hydroxyecdysone (20E) (Figure 1).

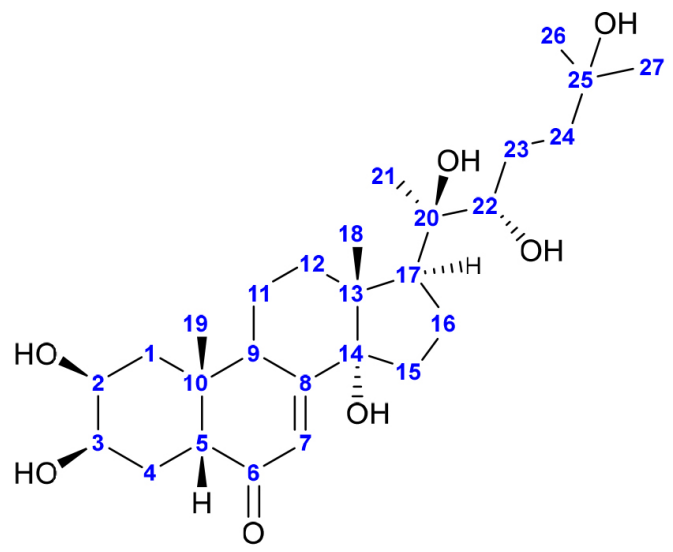

Figure 1. (22R)-2 $\beta, 3 \beta, 14 \alpha, 20,22,25$-hexahydroxy$5 \beta$-cholest-7-en-6-one

The spectral data were compared with those available in the literature ${ }^{18,19}$. This substance belongs to the group of ecdysteroids, which are polyhydroxylated steroids. $20 \mathrm{E}$ is the most biologically active substance in the group ${ }^{20}$ and has been found in other species of the genus Gomphrena such as, G. affinis; G. canescens; G. cunninghamii; G. dispersa e G. haageana; G. officinalis; G. celosioides; G. haenkeana; G. meyeniana, and G. perenis. ${ }^{11}$

Given its relatively high presence in the extract, it is possible that $20 \mathrm{E}$ may justify, in addition to the other results described here, the use of Gomphrena vaga Mart. in traditional medicine. Several studies have demonstrated the biological properties of $20 \mathrm{E}^{21,22,23}$, including analgesic activity. ${ }^{24}$ In addition, other plants such as Cyanotis arachnoidea, Helleborus sp., Leuzea carthamoides, Pfaffia iresinoides e Polypodium decumanum, popularly used as analgesics, antidiabetics, anti-inflammatory, anthelmintic, antidepressant, tonics, among others, have these effects provenly due to the presence of ecdysteroids. ${ }^{25}$

\subsection{Total phenolics and antioxidant activity}

The presence of compounds with antioxidant activity in food sources is of great importance, since oxidative stress, caused by the excess of free radicals in the body, is responsible for triggering a series of chronic diseases. ${ }^{26,27}$ Many authors attribute this antioxidant property of food sources and also of plant extracts, to phenolic compounds, which include flavonoids, phenolic acids, and tannins. ${ }^{28,29}$ Given the importance of phenolic compounds in the elimination of free radicals, their content in the extracts and fractions of the aerial parts and the root of G. vaga was determined by the Folin-Ciocalteu (FC) method. Benabderrahim and col., ${ }^{30}$ states that the investigation of the antioxidant potential of plant extracts must involve the antioxidant activity and the composition of phenolic compounds.

The values obtained for the FC assay varied between 5.06 and $385.15 \mathrm{mg} \mathrm{GAE} \cdot \mathrm{g}^{-1}$ of extract (Table 1). The fraction with the highest total phenolic content was the ethyl acetate fraction of the leaves, with $385.15 \mathrm{mg} \mathrm{GAE} \cdot \mathrm{g}^{-1}$ of extract. The extracts and fractions of the leaves showed a higher content of phenols in relation to their stem and root equivalents.

Table 1. Total phenolic content of extracts and fractions of the leaves, stem, and root of G. vaga Mart

\begin{tabular}{|c|c|}
\hline Sample & Total Phenolics $^{\text {a }}( \pm$ DP $)$ \\
\hline \multicolumn{2}{|c|}{ Methanolic extract } \\
\hline Stem & $48.28( \pm 0.032)$ \\
\hline Leaf & $211.99( \pm 0.043)$ \\
\hline Root & $10.48( \pm 0.016)$ \\
\hline \multicolumn{2}{|c|}{ Hexane fraction } \\
\hline Stem & $11.45( \pm 0.008)$ \\
\hline Leaf & $35.25( \pm 0.006)$ \\
\hline Root & $5.06( \pm 0.002)$ \\
\hline \multicolumn{2}{|c|}{ Chloroform fraction } \\
\hline Stem & $167.43( \pm 0.093)$ \\
\hline Leaf & $248.35( \pm 0.052)$ \\
\hline Root & $63.69( \pm 0.009)$ \\
\hline \multicolumn{2}{|c|}{ Ethyl acetate fraction } \\
\hline Stem & $134.10( \pm 0.039)$ \\
\hline Leaf & $385.15( \pm 0.029)$ \\
\hline Root & $107.91( \pm 0.054)$ \\
\hline
\end{tabular}

${ }^{a}\left(\mathrm{mg} \mathrm{GAE} \cdot \mathrm{g}^{-1}\right.$ of sample $)$

The crude extracts of the root and stem exhibited low levels of phenolic compounds, 10.48 and $48.28 \mathrm{mg} \mathrm{GAE} \mathrm{g}^{-1}$, respectively, compared to the chloroform and ethyl acetate fractions. Other authors have also observed this discrepancy between the content of phenolic compounds in crude extracts and polar fractions. Morales and Paredes ${ }^{31}$, determined the phenol content of the Lampaya medicinalis species and noted that the ethyl acetate fraction had a higher phenol content compared to the other fractions and crude extract; the values found were: $101.26 \mathrm{mg} \mathrm{GAE} \mathrm{g}^{-1}$ fraction for the ethyl acetate fraction and $49.18 \mathrm{mg} \mathrm{mg} \mathrm{GAE} \mathrm{g}^{-1}$ fraction for the crude hydroethanolic extract, which is a significant difference. Reddy and col..$^{32}$ evaluated the phenol content of the crude extract and fractions of the Leea indica species and, also observed that the phenol content in the crude ethanolic extract was lower than that of the aqueous fraction, 19.15 and $45.03 \mathrm{mg} \mathrm{GAE} \mathrm{g}^{-1}$ of extract respectively; the authors attributed this significant difference between the crude extract and the fraction in water to the higher concentration of phenolic compounds in this fraction.

These discrepancies frequently observed in the quantification of phenols in plant extracts also can be, 
probably associated with the nature of the method, which is spectrophotometric. The presence of other constituents in the extracts, other than those of interest, can "mask" the result, which often happens with spectrophotometric methods. A study by Munõz Bernal and col. ${ }^{33}$ showed the interference of sugars during the quantification of total phenols by the FC method; fructose increased the response of the method and overestimated the phenolic content of the evaluated extract and mannose underestimated.

Antioxidant activity was measured using DPPH• (2,2-diphenyl-1-picrylhydrazyl), which is a stable nitrogen free organic radical. This method is widely used to estimate the antioxidant capacity of plant extracts or purified compounds..$^{30}$ The effective concentration values $\left(\mathrm{EC}_{50}\right)$ are shown in Table 2.

Table 2. Antioxidant activity of extracts and fractions from different parts of $G$. vaga

\begin{tabular}{|c|c|}
\hline Sample & $\mathrm{EC}_{50} \mu \mathrm{g} \cdot \mathrm{ml}^{-1}( \pm \mathrm{DP})$ \\
\hline \multicolumn{2}{|c|}{ Methanolic extract } \\
\hline Stem & $74.91( \pm 1.36)$ \\
\hline Leaf & $58.72( \pm 0.59)$ \\
\hline Root & $63.20( \pm 0.94)$ \\
\hline \multicolumn{2}{|c|}{ Hexane fraction } \\
\hline Stem & $75.80( \pm 2.28)$ \\
\hline Leaf & $57.85( \pm 2.87)$ \\
\hline Root & $63.69( \pm 2.03)$ \\
\hline \multicolumn{2}{|c|}{ Chloroform fraction } \\
\hline Stem & $68.46( \pm 5.33)$ \\
\hline Leaf & $53.50( \pm 0.91)$ \\
\hline Root & $50.99( \pm 0.78)$ \\
\hline \multicolumn{2}{|c|}{ Ethyl acetate fraction } \\
\hline Stem & $67.65( \pm 2.56)$ \\
\hline Leaf & $49.22( \pm 1.82)$ \\
\hline Root & $51.89( \pm 3.75)$ \\
\hline \multicolumn{2}{|c|}{ Isolated compound } \\
\hline 20-hydroxyecdysone & $50.55( \pm 0.13)$ \\
\hline \multicolumn{2}{|c|}{ Controls } \\
\hline Ascorbic acid & $58.85( \pm 0.46)$ \\
\hline Gallic acid & $38.90( \pm 1.47)$ \\
\hline
\end{tabular}

The fraction with the greatest antioxidant potential is the ethyl acetate fraction of the leaf with $\mathrm{EC}_{50}$ of $49.22 \mu \mathrm{g} \mathrm{mL}^{-1}$, followed by the fractions chloroform and ethyl acetate of the root with 50.99 and $51.89 \mu \mathrm{g} \mathrm{mL}^{-1}$ respectively. It is noteworthy that these values are lower than that presented by the standard ascorbic acid, which was $58.77 \mu \mathrm{g} \mathrm{mL}^{-1}$. It can also be observed that some extracts and fractions presented $\mathrm{EC}_{50}$ values lower than that of ascorbic acid, which includes the crude extract of the leaf, the hexane, and chloroform fractions of the leaf. The fraction with the highest $\mathrm{EC}_{50}$ value was the stem hexane fraction, with $75.80 \mu \mathrm{g} \mathrm{mL}^{-1}$.
Although the crude extract and the root fractions had a lower content of phenolic compounds, compared to extracts and fractions from other parts of the plant, the antioxidant activity of these samples was, in some cases, greater than the fractions of leaves and stem. For example, the chloroform fraction of the root has the lowest $\mathrm{EC}_{50}$ value. This observation may be related to the presence of $20 E$, which had an $\mathrm{EC}_{50}$ value of $50.55 \mu \mathrm{g} \mathrm{mL}^{-1}$. Studies have shown that ecdysteroids have antioxidant activity, specifically 20-hydroxyecdysone, in several studies, have demonstrated their antioxidant effects. ${ }^{24}$ In a study by Nejma and col. ${ }^{34}$ for example, 20-hydroxyecdysone showed greater antioxidant potential by the DPPH method, compared to the other compounds tested. 20E activity may be attributed mainly to the $\alpha-\beta$-unsaturated ketone conjugation system. This fact shows that secondary plant metabolites, in addition to phenolic compounds, contribute to the antioxidant potential of plant extracts.

\subsection{Antibacterial activity}

The crude extracts and organic fractions from different parts of the G. vaga species were qualitatively evaluated, using the agar diffusion method, against some bacteria, and the results are shown in Table 3.

All extracts and fractions were considered active against the strain Staphylococcus epidermidis, with inhibition halos between 9.09 and $12.80 \mathrm{~mm}$. The diameters of the halos formed did not show significant differences between the concentrations evaluated of the same extract and/or fraction and also between the different extracts, at the $95 \%$ confidence level, by the $\mathrm{F}$ test. This is a very promising result since, as other members of the Staphylococcus genus, S. epidermidis can pose a serious risk to public health, due to the infections it can cause and antibiotic-resistant strains, such as methicillin. ${ }^{35}$ S. epidermidis is the most common coagulase-negative Staphylococcus separated from bloodstream-related infections. This bacterium is mainly associated with infections caused by implants, such as heart valve prostheses and joint prostheses, whose infectious mechanism involves the formation of biofilm. ${ }^{36}$

In the case of the bacterium Enterococcus faecalis, only the fractions in ethyl acetate of the leaves and the root were active, at a concentration of $100 \mathrm{mg} \mathrm{mL}^{-1}$. The crude methanolic extract of the leaves, at the two concentrations evaluated and the chloroform fraction of the stem, also exhibited activity at a concentration of $100 \mathrm{mg} \mathrm{mL}^{-1}$. Enterococcus faecalis is responsible for 80-90\% of infections caused by Enterococcus spp., and is the most common species recorded..$^{37}$ There was no formation of inhibition halos against the bacteria Escherichia coli and Staphylococcus aureus, in the test used, at the evaluated concentrations.

\subsection{Fatty acids identification}

The composition of fatty acids, obtained as their methyl 
Table 3. Antibacterial activity of the extracts and fractions of the different G. vaga parts.

\begin{tabular}{|c|c|c|c|c|}
\hline Extracts/Fractions & Part of the plant & Concentration mg.ml ${ }^{-1}$ & S. epidermidis (mm) & E. faecalis $(\mathrm{mm})$ \\
\hline \multirow{6}{*}{ Crude extract } & \multirow{2}{*}{ Stem } & 400 & $10.54 \pm 0.662$ & - \\
\hline & & 200 & $10.47 \pm 0.456$ & - \\
\hline & \multirow{2}{*}{ Leaf } & 400 & $9.68 \pm 0.325$ & $9.24 \pm 0.347$ \\
\hline & & 200 & $9.09 \pm 0.170$ & $7.85 \pm 0.127$ \\
\hline & \multirow{2}{*}{ Root } & 400 & $11.76 \pm 0.652$ & - \\
\hline & & 200 & $10.60 \pm 0.279$ & - \\
\hline \multirow{6}{*}{ Hexane } & \multirow{2}{*}{ Stem } & 100 & $10.98 \pm 0.593$ & - \\
\hline & & 50 & $12.09 \pm 1.031$ & - \\
\hline & \multirow{2}{*}{ Leaf } & 100 & $10.54 \pm 0.832$ & - \\
\hline & & 50 & $10.80 \pm 0.950$ & - \\
\hline & \multirow{2}{*}{ Root } & 100 & $12.80 \pm 1.08$ & - \\
\hline & & 50 & $11.79 \pm 0.809$ & - \\
\hline \multirow{6}{*}{ Chloroform } & \multirow{2}{*}{ Stem } & 100 & $11.94 \pm 0.175$ & $11.56 \pm 0.928$ \\
\hline & & 50 & $11.22 \pm 1.827$ & - \\
\hline & \multirow{2}{*}{ Leaf } & 100 & $12.29 \pm 1.224$ & - \\
\hline & & 50 & $12.39 \pm 1.05$ & - \\
\hline & \multirow{2}{*}{ Root } & 100 & $12.80 \pm 1.08$ & - \\
\hline & & 50 & $11.52 \pm 1.022$ & - \\
\hline \multirow{6}{*}{ Ethyl acetate } & \multirow{2}{*}{ Stem } & 100 & $9.83 \pm 0.05$ & - \\
\hline & & 50 & $10.37 \pm 0.197$ & - \\
\hline & \multirow{2}{*}{ Leaf } & 100 & $12.22 \pm 0.942$ & $9.53 \pm 0.153$ \\
\hline & & 50 & $10.82 \pm 0.191$ & - \\
\hline & \multirow{2}{*}{ Root } & 100 & $11.96 \pm 0.779$ & $13.37 \pm 1.026$ \\
\hline & & 50 & $12.57 \pm 0.284$ & - \\
\hline Lactic acid & - & $40 \%(\mathrm{v} / \mathrm{v})$ & $17.67 \pm 0.334$ & $29.76 \pm 1.858$ \\
\hline
\end{tabular}

- = Not observed.

esters, in the hexane fractions of the stem, leaves, and roots of $G$. vaga are described in Table 4.

In leaves and stem, the major components were the polyunsaturated linoleic and alpha-linolenic fatty acids. Palmitic acid was the predominant saturated fatty acid found, and in the leaves hexane fraction, it was the single fatty acid found. In the stem, in addition to the palmitic acid, the saturated stearic, lauric, and myristic acids were identified in small amounts. The hexane fraction of the root showed a higher number of fatty acid components. The fatty

Table 4. Fatty acid components of leaves, stem and root of Gomphrena vaga Mart

\begin{tabular}{|c|c|c|c|c|c|c|c|c|c|}
\hline \multirow{2}{*}{ Fatty acid } & \multicolumn{3}{|c|}{$\mathrm{HFL}^{\mathrm{a}}$} & \multicolumn{3}{|c|}{$\mathrm{HFS}^{\mathrm{b}}$} & \multicolumn{3}{|c|}{$\mathrm{HFR}^{\mathrm{c}}$} \\
\hline & $\mathrm{RT}^{\mathrm{d}}$ & $\mathrm{S} \%$ & RA & $\mathrm{TR}^{\mathrm{d}}$ & $\mathrm{S} \%$ & RA & RT & $\mathrm{S} \%$ & $\mathrm{RA}^{\mathrm{e}}$ \\
\hline Linoleic acid & 38.707 & 95 & 25.78 & 38.713 & 93 & 24.22 & 25.659 & 94 & 19.57 \\
\hline Alpha-linolenic acid & 38.841 & 90 & 40.96 & 38.852 & 96 & 52.02 & - & - & - \\
\hline Oleic acid & 38.936 & 92 & 3.62 & - & - & - & 26.889 & 90 & 9.46 \\
\hline 7-Octadecenoic acid & - & - & - & - & - & - & 25.818 & 90 & 14.83 \\
\hline Palmitoleic acid & - & - & - & - & - & - & 21.971 & 95 & 6.63 \\
\hline Stearic acid & 39.316 & 96 & 2.11 & - & - & - & 26.156 & 95 & 6.17 \\
\hline Palmitic acid & 33.729 & 95 & 24.09 & 33.739 & 93 & 23.73 & 22.444 & 95 & 20.48 \\
\hline Lauric acid & 19.806 & 95 & 1.35 & - & - & - & - & - & - \\
\hline Myristic acid & 26.995 & 95 & 2.09 & - & - & - & 18.248 & 93 & 1.31 \\
\hline Pentadecanoic acid & - & - & - & - & - & - & 20.355 & 94 & 2.69 \\
\hline Heptadecanoic acid & - & - & - & - & - & - & 24.300 & 94 & 5.62 \\
\hline
\end{tabular}

$\mathrm{RT}=$ Retention time in minutes; $\mathrm{RA}=$ relative area; $\% \mathrm{~S}=$ Similarity $(\%) ;{ }^{\mathrm{a}}$ Hexanic fraction of the leaves; ${ }^{\mathrm{b}}$ Hexanic fraction of the stem; ${ }^{\mathrm{c}}$ Hexanic fraction of the roots; ${ }^{\mathrm{d}}$ method A; ${ }^{\mathrm{e}}$ method B 
acids present in greater quantity were palmitic, linoleic, and 7-octadecenoic acid.

According to Freije and col..$^{38}$, fatty acids, which are building blocks of most lipids, have important properties, which could evidence the use of plants in traditional medicine as a treatment for a wide variety of diseases. The omega- 6 and omega- 3 polyunsaturated fatty acids, considered the two main families of this type of acid, are derived from linoleic and $\alpha$-linoleic acids, respectively. Both fatty acids can be synthesized in plants and are therefore essential components that should be included in the diet, especially from plants, since they cannot be synthesized in animal tissues. ${ }^{38,39}$

\section{Conclusion}

Given the results obtained, it is possible to state that the species Gomphrena vaga Mart. has a great potential for the search of substances with pharmaceutical potential. The phytochemical investigation of the root extract, resulted in the isolation of 20-hydroxyecdysone, a phytoecdysteroid with important medicinal properties. The amount of 20 -hydroxyecdysone present in the root, $0.95 \%$ of the dry matter, demonstrates the possibilities inherent to the exploration of this plant, which could be used for further studies on the preparation of phytotherapeutics.

The antioxidant property of $G$. vaga was evidenced by the DPPH antioxidant test, mainly by the chloroform and ethyl acetate fractions. The fraction with the highest antioxidant potential was the ethyl acetate fraction of the leaves, with an $\mathrm{EC}_{50}$ value of $49.22 \mu \mathrm{g} \mathrm{mL}^{-1}$. The total phenolic assay showed the presence of these compounds in all extracts and fractions, being higher in the fractions of the leaves.

The antibacterial test demonstrated that $S$. epidermidis and $E$. faecalis strains were susceptible to the tested extracts and fractions, however only a few extracts and fractions were able to inhibit $E$. faecalis growth.

Therefore, the present work shows the results of phytochemical and biological investigations for a species used in popular medicine yet little unexplored scientifically. The results obtained demonstrate the potential of this species, in addition to giving a scientific endorsement to the ethnomedical indications described for that species.

\section{Acknowledgments}

We are grateful to the Núcleo de Instrumentação para Pesquisa e Ensino (NIPE) do Centro de Equipamentos and Serviços Multiusuários (CESM-ICAQF) from Instituto de Ciências Ambientais, Químicas e Farmacêuticas of UNIFESP - Campus Diadema for the LC-ESI-MS/MS e RMN de ${ }^{1} \mathrm{H}$ e ${ }^{13} \mathrm{C}$ analysis. We also thank the Instituto
Federal de Educação, Ciência e Tecnologia Baiano (IF Baiano) for the partnership, the Coordenação de Aperfeiçoamento de Pessoal de Nível Superior (CAPES) and the Conselho Nacional de Desenvolvimento Científico e Tecnológico (CNPQ).

\section{References}

1. Montanari, C. A.; Bolzani, V. S.; Planejamento racional de fármacos baseado em produtos naturais. Química Nova 2001, 24, 105. [CrossRef]

2. Atanasov, A. G.; Waltenberger, B.; Pferschy-Wenzing, E. M.; Linder, T.; Wawrosch, C.; Uhrin, P.; Temml, V.; Wang, L.; Schwaiger, S.; Heiss, E. H.; Rollinger, J. M.; Schuster, D.; Breuss, J. M.; Bochkov, V.; Mihovilovic, M. D.; Kopp, B.; Bauer, R.; Dirsch, V. M.; Stuppner, H.; Discovery and resupply of pharmacologically active plant-derived natural products: A review. Biotechnology Advances 2015, 33, 1582. [CrossRef]

3. Cragg, G. M.; Newman, D. J.; Natural products: A continuing source of novel drug leads. Biochimica et Biophysica Acta 2013, 1830, 3670. [CrossRef] [PubMed]

4. Dutra, R. C.; Campos, M. M.; Santos, A. R. S.; Calixto, J. B.; Medicinal Plants in Brazil: Phamacological studies, drug Discovery, chellenges and perspectives. Pharmacological Research 2016, 112, 4. [CrossRef] [PubMed]

5. Dosumo, O. O.; Idowu, P. A.; Onocha, P. A.; Ekundayo, O.; Isolation of 3-(4-hydroxyphenyl) methylpropenoate and bioactivity of Gomphrena celosioides extracts. EXCLI Journal 2010, 9, 173. [PubMed]

6. Pomilio, A. B.; Buschi, C. A.; Tomes, C. N.; Viale, A. A.; Antimicrobial constituents of Gomphrena martiana and Gomphrena boliviana. Journal of Ethnopharmacology 1992, 36, 155. [CrossRef]

7. Pomilio, A. B.; Solá, G. A. R.; Mayer, A. M. S.; Rumi, L. S.; Antitumor and cytotoxic screen of 5,6,7-trisubstituted flavones from Gomphrena martiana. Journal of Ethnopharmacology 1994, 44, 25. [CrossRef]

8. Sharma, N.; Sharma, P.; Vijayvergia, R.; Evaluantion of Phytochemical and Antioxidant Activity of some Medinical Plants of Family Amaranthaceae. Journal of Pharmacy Research 2012, 5, 4713. [Link]

9. Roriz, C. L.; Barros, L.; Carvalho, A. M.; Buelga, C. S.; Ferreira, I. C. F. R.; Pterospartum tridentatum, Gomphrena globosa and Cymbopogon citratus: A phytochemical study focused on antioxidant compounds. Food Research International 2014, 62, 684. [CrossRef]

10. Hamiduzzaman, M.; Evaluation of central and peripheral analgesic activity whole plant Gomphrena Globosa (L) (Family: Amaranthaceae). International Research Journal of Pharmacy 2013, 4, 54. [Link]

11. Salvador, M. J.; Andreazza, N. L.; Aislan, C. R. F.; Pereira, P. S.; França, S. C.; Zucchi, L. A. D.; Dias, D. A.; Bioactive Chemical Constituents and Biotechnological Production of Secondary Metabolites in Amaranthaeceae Plants, Gompheneae Tribe; Ohran, I. E., ed.; Bentham e-books, 2012, cap. 8. [Link] 
12. Siqueira, J. C. O.; Tese de Doutorado, Universidade Estadual de Campinas, 1991. [Link]

13. Sítio da Flora do Brasil 2020. Disponível em: <http:// reflora.jbrj.gov.br/reflora/listaBrasil/FichaPublicaTaxonUC/ FichaPublicaTaxonUC.do?id=FB4317>. Acesso em: 15 fevereiro 2019.

14. Agra, M. F.; Freitas, P. F.; Filho, J. M. B.; Synopsis of the plants known as medicinal and poisonous in Northeast of Brazil. Brazilian Journal of Pharmacognosy 2007, 17, 114. [CrossRef]

15. Albuquerque, U. P.; Medeiros, P. M.; Almeida, A. L. S.; Monteiro, J. M.; Neto, E. M. F. L.; Melo, J. G.; Santos, J. P.; Medicinal plants of the caatinga (Semi-arid) vegetation of $\mathrm{NE}$ Brazil: A quantitative approach. Journal of Ethnopharmacology 2007, 114, 325. [CrossRef] [PubMed]

16. Sousa, C. M. M.; Silva, H. R.; Vieira.JR., G. M.; Ayres, M. C. C.; Costa, C. L. S.; Araújo, D. S.; Cavalcante, L. C. D.; Barros, E. D. S.; Araújo, P. B. M.; Brandão, M. S.; Chaves, M. H.; Fenóis Totais e atividade antioxidante de cinco plantas medicinais. Química Nova 2007, 30, 351. [CrossRef]

17. Bauer, A. W.; Kirby, W. M. M.; Sherris, J. C.; Turch, M.; Antibiotic susceptibility testing by a standardized single disk method. The American Journal of Clinical Pathology 1966, 45,493. [CrossRef] [PubMed]

18. Girault, J. P.; Lafont, R.; The complete ${ }^{1} \mathrm{H}-\mathrm{NMR}$ assignment of ecdysone and 20-hydroxyecdysone. Journal of Insect Physiology 1988, 34, 701. [CrossRef]

19. Vokác, K.; Buděšínsky, M.; Harmatha, J.; Kohoutová, J.; Ecdysteroid constituents of the mushroom Tapinella panuoides. Phytochemistry 1998, 49, 2109. [CrossRef]

20. Dinan, L.; Phytoecdysteroids: biological aspects. Phytochemistry, 2001, 57, 325. [CrossRef] [PubMed]

21. Buniam, J.; Chukijrungroat, N.; Rattanavichit, Y.; Surapongchai, J.; Weerachayaphorn, J.; Bupha-Intr, T.; Saengsisuwan, V.; 20-Hydroxyecdysone ameliorates metabolic and cardiovascular dysfunction in high-fathigh-fructose-fed ovariectomized rats. BMC Complementary Medicine and Therapies 2020, 20, 140. [CrossRef] [PubMed]

22. Bajguz, A.; Bakala, I.; Talarek, M.; Ecdysteroids in Plants and their Pharmacological Effects in Vertebrates and Humans. Studies in Natural Products Chemistry 2015, 45, 121. [CrossRef]

23. Báthori, M.; Phytoecdysteroids Effects on Mammalians, Isolation and Analysis. Mini Reviews in Medicinal Chemistry 2002, 2, 285. [PubMed]

24. Lafont, R.; Dinan, L.; Pratical uses for ecdysteroids in mammals including humans: and update. Journal of Insect Science $\mathbf{2 0 0 3}$ 3, 1. [CrossRef] [PubMed]

25. Báthori, M.; Pongrácz, Z.; Phytoecdysteroids - From isolation to Their Effects on Humans. Current Medicinal Chemistry 2005, 12, 153. [PubMed]

26. Rao, S. P.; Kalva, S.; Yerramilli, A.; Mamidi, S.; Free radicals and Tissue Damage: Role of Antioxidants. Free Radicals and Antioxidants 2011, 1, 2. [CrossRef]
27. Pham-Huy, L. A.; HE, H.; Pham-Huy, C.; Free radicals, Antioxidants in Disease and Health. International Journal of Biomedical Science 2008, 4, 89. [PubMed]

28. D'archivio, M.; Filesi, C.; Benedetto, R.; Gargiulo, R.; Giovannini, C.; Masella, R.; Polyphenols, dietary sources and bioavailability. Ann Ist Super Sanità 2007, 43, 348. [PubMed]

29. Dai, J.; Mumper, R. J.; Plant Phenolics: Extraction, Analysis and Their Antioxidant and Anticancer Properties. Molecules 2010, 15, 7313. [CrossRef] [PubMed]

30. Banabderrahim, M. A.; Yahia, Y.; Bettaieb, I.; Elfalleh, W.; Nagaz, K.; Antioxidant activity and phenolic profile of a collection of medicinal plants from Tunisian arid and Saharan regions. Industrial Crops \& Products 2019, 138, 111427. [CrossRef]

31. Morales, G.; Paredes, A.; Antioxidant activities of Lampaya medicinalis extracts and their main chemical constituents. BMC Complementary Medicine and Therapies 2014, 14, 259. [CrossRef] [PubMed]

32. Reddy, N. S.; Navanesan, S.; Sinniah, S. K.; Whalab, N. A.; Sim, K. S.; Phenolic content, antioxidant effect and cytotoxic activity of Leea indica leaves. BMC Complementary Medicine and Therapies 2012, 12, 128. [CrossRef

33. Muñoz-Bernal, O.A.; Torres-Aguirre, G. A.; Núñez-Gastélum, J. A.; la Rosa, L. A.; Rodrigo-García, J.; Ayala-Zavala, J. F.; Álvarez-Parrilla, E.; Nuevo acercamiento a la interacción del reactivo de Folin-Ciocalteu con azúcares durante la cuantificación de polifenoles totales. TIP Revista especializada em Ciencias Químico-Biológicas, 2017, 20, 23. [CrossRef]

34. Nejma, A. B.; Nguir, A.; Jannet, H. B.; Hamza, M. A.; Daïch, A.; Othman, M.; Lawson, A. M.; New septanoside and 20-hydroxyecdysone septanoside derivative from Atriplex portulacoides roots with preliminary biological activities. Bioorganic \& Medicinal Chemistry Letters 2015, 25, 1665. [CrossRef] [PubMed]

35. Founou, L. L.; Founou, R. C.; Allam, M.; Ismail, A.; Essack, S. Y.; Draft genome sequence of a methicillin-resistant Staphylococcus epidermidis isolate from swine. Jornal of Global Antimicribial Resistance 2018, 15, 250. [CrossRef] [PubMed]

36. Wadood, A.; Ghufran, M.; Khan, A.; Azam, S. S.; Uddin, R.; Waqas, M.; Saleem, S.; The methicillin-resistant S. epidermidis strain RP62A genome mining for potential novel drug targets identification. Gene Reports 2017, 8, 88. [CrossRef] [PubMed]

37. Mohamed, J. A.; Huang, D. B.; Biofilm formation by enterococci. Journal of Medical Microbiology 2007, 56, 1581. [CrossRef]

38. Freije, A. Alkhuzai, J. Al-Laith, A. A.; Fatty acid composition of three medicinal plants from Bahrain: New potential sources of $\lambda$-linolenic acid and dihomo- $\lambda$-linolenic. Insdustrial Crops and Products 2013, 43, 218. [CrossRef]

39. Siddiqui, R. A., Harvey, K. A., Zaloga, G. P.; Modulation of enzymatic activities by $n-3$ polyunsaturated fatty acids to support cardiovascular health. Journal of Nutritional Biochemistry 2008, 19, 417. [ㄷossRef] 